\title{
Catastrophe or Catalyst? Reflections on COVID's Impact on Community Colleges
}

\author{
Thomas Brock* with Cameron Diwa \\ Community College Research Center, Teachers College \\ Columbia University
}

\begin{abstract}
The COVID-19 pandemic led to a steep decline in enrollments at community colleges, especially among Black, Hispanic, and Indigenous populations, males, and part-time students. The Coronavirus Aid, Relief, and Economic Security Act (CARES) and the American Rescue Plan (ARP) Acts provided funds for emergency aid and engaging disconnected students, and community colleges moved swiftly to shift services and instruction online. In this essay, we discuss how students and community colleges responded to the pandemic and what their experiences reveal about inequities in higher education. We argue that the crisis was worsened by years of underinvestment in these institutions and by entrenched structures and practices that do not address the needs and aspirations of many students. We review evidence on reforms that aim to remake community colleges in ways that improve student outcomes. While COVID-19 can rightly be viewed as a catastrophe, it may also serve as a catalyst for fundamental and lasting improvements in how community colleges are funded, organized, and operated to help more students achieve their goals.
\end{abstract}

Keywords: community colleges; enrollment; COVID; equity; reforms

*Contact: twb22@tc.columbia.edu 


\section{Introduction}

Sixty-six million years ago, a large asteroid struck near the Yucatan Peninsula and caused such widespread climactic change that many of Earth's plant and animal species became extinct, including the dinosaurs. It also created conditions that allowed mammals to flourish. The asteroid serves as a kind of metaphor for the COVID-19 pandemic: The virus seemingly burst out of nowhere and led to devastating loss of human life across the globe. In the United States, it upended higher education, with particularly severe consequences for the nation's community colleges and their students. In this essay, we reflect on what happened and what it reveals about inequities in higher education. We also consider the opportunity created by the pandemic to rethink and remake community colleges to better serve their students.

\section{COVID and Higher Education Enrollment}

It will be some time before we understand the full effects of COVID on the education and employment outcomes of current college students, but we already know its effects on enrollment. As shown in Figure 1, enrollments in community colleges had already been on the decline for about a decade before COVID hit, owing to a gradual reduction in the number of young people of traditional college age, a growing economy that drew some potential students away from the classroom and into the labor market, and increased competition from online colleges and traditional four-year institutions. Enrollments at four-year colleges and universities increased slightly during this same period (National Center for Education Statistics [NCES], 2021a). Following the onset of the pandemic in 2020, the enrollment patterns at two- and four-year institutions diverged sharply, with community colleges experiencing nearly an $11 \%$ decline from fall 2019 to fall 2020, versus a decline of .25\% for four-year colleges and universities (NCES, 2021a, 2021c).

Figure 1: Total Fall Undergraduate Enrollment, 2011-2020

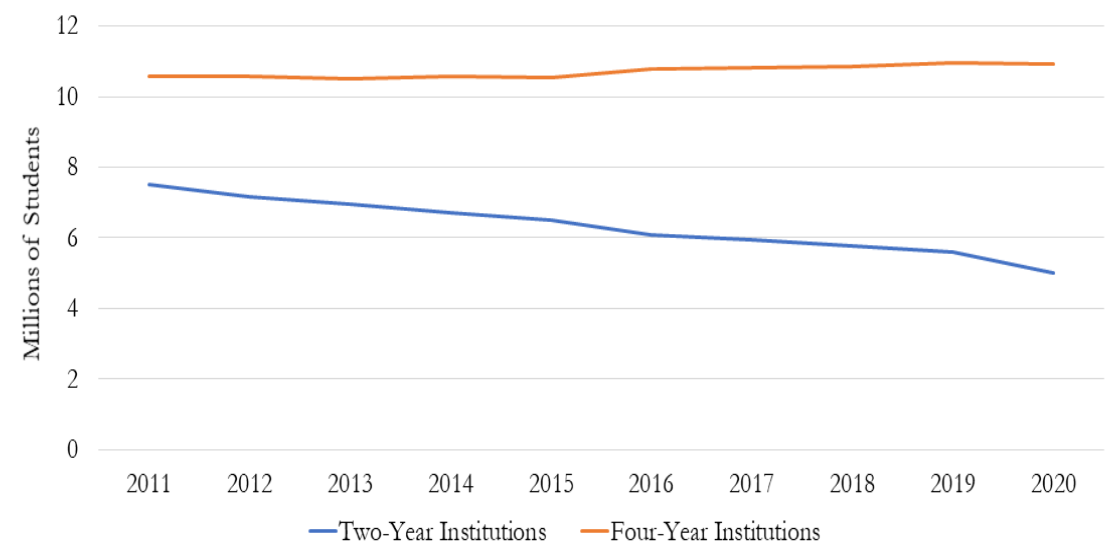

Source: National Center for Education Statistics, 2021a and 2021c. 
As shown in Figure 2, community colleges suffered a loss of enrollment from every major racial/ethnic group (NCES, 2021b, 2021c). The sharpest declines were among Black, Hispanic, and Indigenous students: Each group experienced a nearly 15\% drop in enrollment from fall 2019 to fall $2020 .^{1}$ The decline for males was nearly twice as large as for females, and the decline for part-time students was larger than for fulltime students. At four-year colleges and universities, the patterns were mixed. Small decreases in enrollment among Indigenous and White students were offset by modest increases in Asian, Black, and Hispanic student enrollment. Male enrollment declined, but female enrollment increased slightly. Four-year institutions lost some full-time students but observed an increase in part-time students.

Figure 2: Percent Change in Undergraduate Enrollment by Subgroup, Fall 2019 to Fall 2020

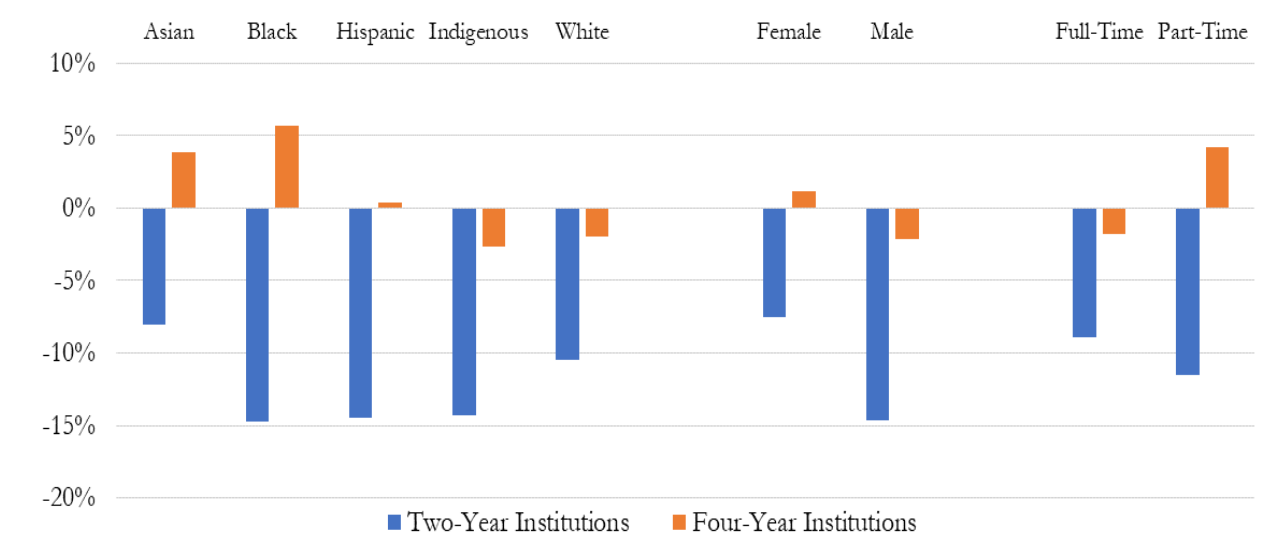

Source: CCRC calculations based on enrollments reported by the National Center for Education Statistics, 2021b and 2021c.

Why do we see these patterns, and why specifically are community college enrollments so much more impacted than enrollments at four-year colleges and universities? The answer lies in part in the different populations that these institutions serve. Relative to four-year institutions, community colleges serve a higher percentage of undergraduates who identify as Black, Hispanic, and Indigenous (NCES, 2021b, 2021c). Data from the Centers for Disease Control and Prevention (CDC) show that these same racial and ethnic groups were disproportionately affected by COVID. Specifically, Hispanic persons were disproportionately represented among all COVID cases in the United States, and Black, Hispanic, and Indigenous persons were disproportionately represented among all COVID deaths (CDC, 2020a, 2020b). The economic effects of COVID were also borne disproportionately by Black and Hispanic persons, who were more likely than Asian or White individuals to suffer job loss and to report difficulty paying their bills after the pandemic started (Parker et al., 2020).

1 Indigenous refers to American Indian and Alaska Native peoples. 
The U.S. Census Bureau's Household Pulse Survey (2021) provides evidence that links health and economic concerns to decisions about college enrollment. Starting in spring 2020, the Bureau randomly selected 100,000 addresses each week to find out how Americans were affected by COVID. The survey included questions on education, including plans for college. The Community College Research Center (CCRC) analyzed responses from approximately 25,000 households that reported plans for community college for at least one member of their household between August and September 2020 (Belfield \& Brock, 2020). Of this group, more than $40 \%$ said that they had canceled all plans for community college, and an additional $15 \%$ said that they were either taking fewer classes or switching programs. The survey also revealed that households with current or prospective community college students canceled plans at more than twice the rate of households with four-year college students (see Figure 3).

Figure 3: Households Canceling or Changing Plans for College, Fall 2020

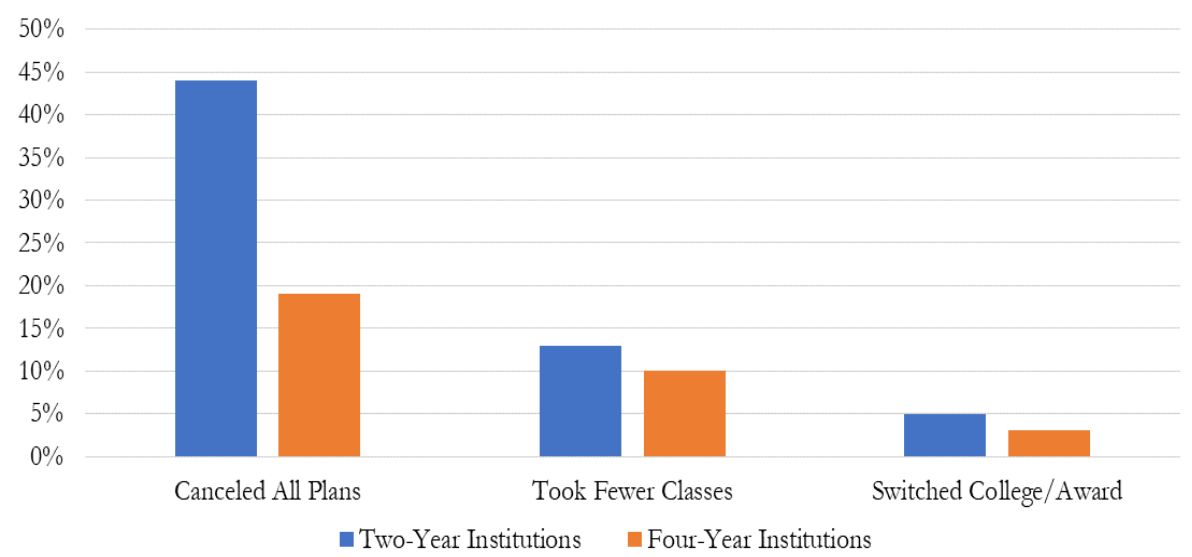

Source: CCRC calculations based on U.S. Census Bureau Household Pulse Survey administered August 19-31 and September 2-14, 2020.

Many factors may cause students to exit higher education, but the survey makes clear that households with plans for community college were impacted differently than households with plans for four-year colleges and universities (see Figure 4). In fall 2020, more than one third of households with plans for community college cited the virus - either contracting it, being concerned about contracting it, or caring for someone who had it - as a significant factor in their decision to cancel college plans; in contrast, $23 \%$ of households with plans for a four-year college or university reported such concerns. The survey also revealed that households with community college plans were nearly twice as likely as households with four-year college plans to cite affordability or changes in financial aid as reasons for canceling their college plans. 


\section{Figure 4: Reasons for Canceling or Changing Plans for College, Fall 2020}

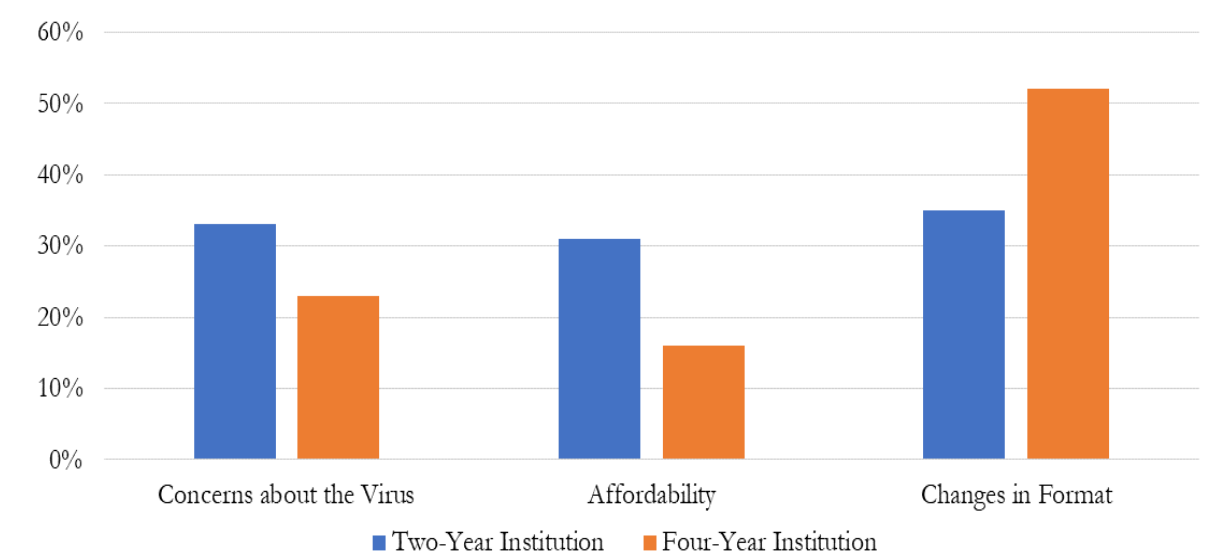

Source: CCRC calculations based on U.S. Census Bureau Household Pulse Survey administered August 19-31 and September 2-14, 2020.

Changes to the content or format of classes (e.g., from in-person to online) also were a factor in canceling or changing plans for college. While the wording of the question was not precise, we presume that the shift to online instruction is what most respondents had in mind. About one third of households with community college plans indicated that changes to the content or format influenced their decision-making, compared to more than half of households with four-year college plans. A closer look at the data revealed the changes in format did not affect all households the same way: For some, it was a deterrent to enrollment, while for others, it had the opposite effect. Notably, households with plans for four-year college were more likely to report that changes in the format of college classes had a net positive effect on their enrollment decisions than households with plans for community college. The Census Bureau survey also revealed that households with community college students were more likely to not have a computer than households with four-year college students (28\% versus 24\%) and more likely to not have an Internet connection (33\% versus $23 \%)$.

The rapid rollout of online instruction by colleges and universities was a significant accomplishment during the pandemic, but it did not meet the needs of all students or make sense for all academic programs. A report by the National Student Clearinghouse Research Center (2020) showed that the field of study with the largest drop in enrollment at two-year institutions from fall 2019 to fall 2020 was basic skills and developmental/remedial education (-37\%). Few students are enthusiastic about developmental education courses in normal times, and students may have been even less inclined to take these courses when they had to dial in remotely. After developmental education, the next five fields with the largest drops in enrollment were precision production $(-18.4 \%)$, physical sciences $(-17.3 \%) \%)$, personal and culinary services (-17.2\%), com -munications technology/technician (-16.2\%), and mechanic and repair technologies $(-15.9 \%)$. The common denominator is that these fields of instruction typically involve 
lab work and hands-on training. For example, aspiring chefs need the experience of cooking over an open flame, and budding mechanics need to learn how to disassemble and reassemble an engine.

\section{Institutional Responses to COVID}

In the early days of the pandemic, when campuses were shut down and students were sent home, higher education leaders feared devastating economic consequences for their institutions and their students. Community colleges were especially vulnerable since their funding is largely based on enrollment and because they serve so many low-income students. Swift action by Congress through the Coronavirus Aid, Relief, and Economic Security Act (CARES Act, 2020) helped by allocating nearly $\$ 14$ billion to support higher education institutions and provide emergency financial aid for college students. Relief was targeted to institutions that served a high percentage of Pell Grant recipients, but community colleges were at a disadvantage relative to four-year institutions because the funding formula was based on full-time equivalent enrollment (i.e., treating two half-time students the same as one full-time student). Nationally, about $63 \%$ of community college students were part-time in 2019 , compared to $26 \%$ of four-year college students (NCES, 2021a). Part-time students do not have less financial need than full-time students; in fact, they often have greater need because they qualify for less student aid and are making ends meet by working while they go to school. A supplemental appropriation to the CARES Act in late 2020 and the American Rescue Plan (ARP) Act of 2021 directed more funding to under-resourced institutions that served students most affected by the pandemic, including more than $\$ 10$ billion to community colleges. Funds were allocated for engaging disconnected students, expanding mental health services, and creating more robust retention programs (U.S. Department of Education, 2021).

As of yet, there is no systematic, nationally representative study of how community colleges used funds from the CARES or ARP Acts and what effects these funds had on their students, though researchers have gleaned some insights through telephone interviews and online forums involving college administrators, faculty, and staff. As described by Goldrick-Rab (2021) in the inaugural issue of this journal, some of these funds went to addressing critical basic needs including food, housing, transportation, and childcare. Amarillo College in Texas gained national recognition for its food pantry and extensive social services, including emergency aid that may be accessed by students within 24 hours-provisions that contributed to its recognition as a "rising star" by the Aspen Institute College Excellence Program (AICEP, 2021a). Despite this promising example, research by the Hope Center for College, Community, and Justice suggests that most colleges struggled during the pandemic to deliver equitable and effective emergency aid programs on a large scale. The Hope Center also found that many colleges did a poor job of advertising the availability of emergency aid or engaging faculty to share information with their students (Goldrick-Rab, 2021). 
Since 2018, the Institute for Evidence-Based Change (IEBC) has been working with 56 community colleges across the country to implement Caring Campus, an initiative designed to engage faculty and nonacademic staff in creating a culture of caring that helps students build relationships with adults on campus who have similar backgrounds, feel a sense of belonging, and have their needs met more quickly and effectively (IEBC, n.d.). Participating colleges receive coaching on how to form teams and introduce behavioral changes designed to improve interactions with students. Though the initiative was developed prior to the pandemic, in spring 2020 IEBC adjusted its approach for a virtual environment in part by developing strategies for staff to contact students via phone, email, and text to let them know they were available to answer questions, respond to concerns, make referrals, and reach out to students with greater needs (Bickerstaff, Barnett, et al., 2021). Staff at San Antonio College in Texas-which won the Aspen Prize for Community College Excellence in 2021 (AICEP, 2021b)—capitalized on the training they received from Caring Campus to contact 20,000 students after the pandemic shut down the campus, with priority given to students who had not previously taken an online course or who resided in low-income neighborhoods; these students may have had less access to computers or the Internet (Phillips \& Horowitz, 2020).

Issues with computer and Internet access loomed large in community colleges' response to the pandemic and in keeping current students enrolled and engaged. CCRC researchers spoke with leaders at 23 colleges around the country that have been working on making structural changes to improve student advising and support services and heard examples of colleges distributing laptop computers and setting up Wi-Fi hotspots in parking lots and other campus locations (Lopez Salazar et al., 2020). Researchers at Wheelhouse: The Center for Community College Leadership and Research at the University of California, Davis, heard similar reports in interviews with 20 community college presidents throughout the state (Cooper et al., 2020). One of their findings was that computers and Wi-Fi connectivity were not always a complete solution, particularly if students were not familiar with how to use technology, lived in tight quarters, or experienced other stresses at home. Lack of comfort with technology and other stresses in students' lives may explain why some institutions, such as Southwest Tennessee Community College in Memphis, reported that hundreds of laptops they purchased went unclaimed (McMurtie, 2021). One of the institutions in the Wheelhouse study, Foothill College in Northern California, responded by hiring 30 students to serve as "technology ambassadors" to help students and faculty set up their equipment and provide technical support (Cooper et al., 2020).

Not surprisingly, colleges that had invested in technological supports for student advising and teaching prior to the pandemic reported an easier time shifting to remote teaching and learning than colleges that had not made such preparation. Wake Tech Community College in North Carolina, for example, had invested in digital infrastructure over a six-year period and trained the vast majority of its full- and part-time faculty in online teaching (Glatter, 2020). Other colleges quickly mobilized training for faculty and staff on how to conduct remote teaching and advising (Cooper et al., 
2020; Lopez Salazar et al., 2020). Because COVID made it impractical to do in-person testing, many colleges also had to make rapid changes in how they assessed the reading, writing, and math skills of incoming students to determine their course placements. In this area at least, COVID may have ushered in better practices than what existed before. Pre-COVID, community colleges generally relied on standardized tests to determine whether students were "college ready," and they placed large numbers of incoming students into developmental education courses. At least four states-Indiana, Virginia, Texas, and Washington-made systemwide decisions during the pandemic to do away with standardized tests so that students did not have to come to campus and potentially be exposed (or expose others) to the virus. Instead, they relied on analysis of high school transcripts and other indicators of past performance that students could report online (Bickerstaff, Kopko, et al., 2021). Their response is backed by a growing body of research, including a large-scale randomized controlled trial in seven New York State community colleges, that indicates that high school grades combined with test scores result in fewer students being placed into developmental courses and higher completion of college-level English and math courses in the first term (Barnett et al., 2020).

To understand faculty perceptions of the impact of the COVID pandemic on teaching and learning, Fox et al. (2020) fielded a nationally representative survey of faculty at two- and four-year institutions in May 2020. Nearly 4,800 faculty responded, and $91 \%$ reported that they transitioned their courses to remote delivery. Fox et al. (2021) conducted two more waves in summer and fall 2020 and analyzed responses from a subset of 852 faculty who taught general education and introductory-level courses at two- and four-year institutions. A majority reported making changes to improve instruction, such as modularizing their courses to accommodate different teaching modalities and conducting frequent assessments to monitor students' learning. Nonetheless, more than two thirds of respondents indicated that they had challenges keeping students engaged, and more than one third indicated challenges in providing additional supports to students. Respondents had persistent concerns about student equity and success, and they noted an increase in students withdrawing from courses, taking incompletes, or receiving letter grades of $\mathrm{D}$ or $\mathrm{F}$.

\section{Opportunities to Forge a Better System}

The pandemic laid bare some of the inequities in higher education. It is well established that community colleges and four-year colleges and universities serve different populations, but the enrollment data make clear how much more vulnerable community college students are in times of crisis. To their credit, federal policymakers and community college leaders moved quickly to keep institutions running and to channel resources to students in need, but even their swift actions were not enough to stave off steep declines in enrollment among Black, Hispanic, and Indigenous students, and among male and part-time students. Community colleges cannot be expected to insulate students from a virus that spread across the globe and had disproportionate impact 
on racially minoritized and low-income communities in the United States. Nonetheless, the crisis was arguably worsened by years of underinvestment in these institutions and by entrenched structures and practices that fail to address the needs and aspirations of far too many students.

Prior to the pandemic, The Century Foundation issued a study documenting how little funding community colleges receive per student relative to four-year colleges and universities even after excluding money for research and other specialized functions. Community colleges spend less than half as much per student on academic instruction as public research universities and a third as much as private research universities, even though community colleges are considered teaching institutions and serve far more low-income students (The Century Foundation, 2019a, 2019b). Using data from the Integrated Postsecondary Education Data System (IPEDS), Deming and Walters (2017) examined the impact of higher education spending between 1990 and 2013 in two- and four-year institutions and found positive and statistically significant impacts of increased spending per student on enrollment and degree completion. The effects were larger at community colleges. Specifically, at two-year colleges, a $10 \%$ increase in funding in a given year led to more than a $14 \%$ increase in credentials awarded in the following years. They hypothesized that higher funding corresponded to more course offerings, reduced waiting lists and class sizes, and improved student guidance. Their analysis is consistent with evidence from two randomized controlled trials of the Accelerated Study in Associate Programs (ASAP), in which an enriched program of blocked courses, intensive advising, and enhanced financial support roughly doubled graduation rates at three City University of New York community colleges (where ASAP originated) and at three Ohio community colleges that replicated the model (Miller et al., 2020). ASAP was designed for students able and willing to attend full-time and provided them with enhanced support for three years, an unusually long time for an intervention. Although ASAP cost more than the colleges' regular programs-over $\$ 5,000$ more per student each year in the original study, and $\$ 1,840$ more per student each year in the Ohio replication-the added investment resulted in a lower cost per degree awarded (Miller et al., 2020; Scrivener et al., 2015).

In the past five years, CCRC has assisted many of the more than 400 community colleges in at least 16 states that are using the guided pathways framework for whole-college reform. Guided pathways is designed to help community college students explore, choose, plan, and complete - in a reasonable time and at less cost-programs that enable them to secure a good job directly or successfully transfer to a bachelor's program (CCRC, 2021). Guided pathways is an antidote to the "cafeteria college" model that evolved on community college campuses in the 1960s and 1970s, in which institutions developed a wide range of courses and programs to satisfy student interests but generally left it to students to seek out advising and supports. Unfortunately, students who are unfamiliar with college or who are struggling academically often do not have a clear understanding of what is required to earn a degree or transfer to a four-year institution and may be reluctant to ask for help. At many institutions, the default is to 
place large numbers of incoming students into developmental education courses that are intended to make them "college ready," but these courses produce mixed effects at best and do not provide credits that count toward degrees (Bettinger et al., 2013; Boatman \& Long, 2018; Jaggars \& Stacey, 2014).

The guided pathways framework calls for wholesale restructuring of academic programs and student supports to address the barriers to success created by the cafeteria college model. It challenges colleges to organize programs into broad fields of study (or meta-majors) to facilitate academic and career exploration and to clarify what students need to do to complete a program or transfer. Ideally, under the guided pathways approach, every student gets help in connecting with faculty and students in their field of interest and in creating an individualized program plan, and every student receives ongoing attention and advising to stay on their chosen path (or to modify it). The framework also focuses on improved student learning by getting students into college-level courses (as opposed to developmental courses) as quickly as possible and by emphasizing active and experiential learning in and beyond the classroom. Guided pathways and ASAP are similar in their emphasis on providing students with more structure and support to help them achieve their goals more quickly and efficiently; a key difference is that guided pathways is designed for part-time as well as full-time students. Their costs also differ: The added expense of guided pathways over colleges' current spending levels is estimated at $\$ 450$ per full-time equivalent student each year, mainly to cover the expense of hiring additional student advisors. CCRC is evaluating the effects of guided pathways on student outcomes in Ohio, Tennessee, and Washington and will publish results in late 2022 (CCRC, 2021).

The Institute of Education Sciences recently released a practice guide on student advising for postsecondary education students that draws on ASAP and other rigorously evaluated interventions to underscore the critical role advisors play and how advising should be delivered to increase the likelihood that students will progress in college and achieve positive outcomes (Karp et al., 2021). A key recommendation is that advising should be comprehensive and designed to address students' academic and nonacademic needs. Another is that it should be focused on developing and sustaining personalized relationships with students throughout their academic career. Under the guided pathways framework, one way that colleges have achieved these goals is by embedding academic advisors within students' field of study so that they get to know students well and are attuned to their needs and interests (Jenkins et al., 2021). San Antonio College in Texas-which, as previously noted, won the 2021 Aspen Prize for Community College Excellence-adopted this approach and credited it with helping to create "a culture of care and attention" that contributed to student success (AICEP, 2021b). The sudden shift to online instruction and services under COVID also highlights the importance of technology to identify students who need the most help (for example, because they stop showing up for classes or earn poor grades) and to facilitate online interactions between students, advisors, and faculty when in-person meetings are not possible (Klempin et al., 2019). 
The pandemic revealed that many community college instructors need more training and better tools to teach online. Previous studies of online learning for community college students have not been encouraging, showing that students in online courses are between $3 \%$ and $15 \%$ more likely to withdraw compared to similar students in face-to-face classes (Xu \& Xu, 2019). Nevertheless, the pandemic forced the question of what happens when instruction can only be delivered online due to a public health crisis or other emergency, or when some students remain fearful of returning to campus even when in-person classes are resumed. The longitudinal survey of two- and fouryear college faculty conducted by Fox et al. (2021) during the pandemic indicates that instructors had reservations about online teaching but that their attitudes improved over time and that they were generally satisfied with how students learned. Anecdotally, CCRC heard reports that online instruction during COVID may have benefited some groups of students, including parents responsible for watching their children, students living in rural areas or other places not well served by public transportation, and introverted students who are more comfortable using chat features than speaking up in classrooms. This "grand unplanned experiment" in online instruction (Fox et al., 2021 , p. 3) points to the need for continuing research on how instructors can make better use of technology regardless of the format: in person, online, or hybrid. It also points to the need to equip every student with a laptop computer upon enrolling in college and to make sure every campus has Wi-Fi hotspots that students can use 24/7, both in normal times and in times of crisis.

The COVID pandemic accelerated the trend of declining enrollments in community colleges and put the academic and career plans of many students on hold. Because of the way community colleges are funded, the pandemic could have triggered severe cuts in programs and services, possibly leading to further drops in community college enrollment and reductions in revenue. Fortunately, emergency funding from the CARES and ARP Acts guarded against major cutbacks, and as of this writing there is a possibility that the Build Back Better Act will include new funding for retention and completion grants and workforce training programs at community colleges (Gravely, 2021). Whatever happens with this legislation, the pandemic has made clear that targeted investment in community colleges and their students is needed-particularly for Black, Hispanic, and Indigenous students, and also for men and part-time students. For too long, community colleges have assumed that their array of offerings and open-access policies are sufficient to keep students coming through the door, but as our CCRC colleagues Davis Jenkins and John Fink (2021) have observed, to build back enrollments, community colleges must ensure that their programs are worth completing. The devastating effects of COVID are undeniable, but sometimes it takes a crisis to move systems into action. From this perspective, COVID may be viewed not as a catastrophe but rather as a catalyst for fundamental and lasting improvements in how community colleges are funded, organized, and operated to help students achieve their goals. 


\section{Acknowledgements}

We would like to thank Clive Belfield for his analysis of the U.S. Census Bureau's Household Pulse survey and Doug Slater for his editorial support and review of the paper. Any errors or omissions are our own.

\section{References}

American Rescue Plan Act of 2021, Public L. No. 117-2. (2021). https://www.congress.gov/117/plaws/publ2/PLAW-117publ2.pdf

Aspen Institute College Excellence Program. (2021a, May 18). Loving students to success: Amarillo College, 2021 Aspen Rising Star. https://highered.aspeninstitute. org/idea/loving-students-to-success/

Aspen Institute College Excellence Program. (2021b, May 18). Making success a given for students: San Antonio College, 2021 Aspen Prize winner. https://highered. aspeninstitute.org/idea/making-success-a-given-for-students/

Barnett, E. A., Kopko, E., Cullinan, D., \& Belfield, C. (2020). Who should take college-level courses? Impact findings from an evaluation of a multiple measures assessment strategy. Center for the Analysis of Postsecondary Readiness. https:// postsecondaryreadiness.org/multiple-measures-impact-findings/

Belfield, C., \& Brock, T. (2020, November 19). Behind the enrollment numbers: How COVID has changed students' plans for community college. Community College Research Center. https://ccrc.tc.columbia.edu/easyblog/covid-enrollment-community-college-plans.html

Bettinger, E. P., Boatman, A., \& Long, B. T. (2013). Student supports: Developmental education and other academic programs. Future of Children, 23(1), 93-115. http://doi:10.1353/foc.2013.0003

Boatman, A., \& Long, B. T. (2018). Does remediation work for all students? How the effects of postsecondary remedial and developmental courses vary by level of academic preparation. Educational Evaluation and Policy Analysis, 40(1), 29-58. https://doi.org/10.3102/0162373717715708

Bickerstaff, S., Barnett, E. A., \& Lopez Salazar, A. (2021). Caring Campus: An initiative to involve community college staff in increasing student success. Columbia University, Teachers College, Community College Research Center. https://ccrc. tc.columbia.edu/publications/caring-campus-initiative-community-college-staff. html

Bickerstaff, S., Kopko, E., Lewy, E. B., Raufman, J., \& Zachry Rutshow, E. (2021). Implementing and scaling multiple measures assessment in the context of COVID-19. Center for the Analysis of Postsecondary Readiness. https://postsecondaryreadiness.org/multiple-measures-scaling-covid-pandemic/

CARES Act, Public L. No. 116-136. (2020). https://www.congress.gov/116/plaws/ publ136/PLAW-116publ136.pdf 
Centers for Disease Control and Prevention. (2020a, December 10). Disparities in COVID-19 illness. https:/www.cdc.gov/coronavirus/2019-ncov/community/ health-equity/racial-ethnic-disparities/increased-risk-illness.html

Centers for Disease Control and Prevention. (2020b, December 10). Disparities in death from COVID-19. https://www.cdc.gov/coronavirus/2019-ncov/community/health-equity/racial-ethnic-disparities/disparities-deaths.html

Community College Research Center. (2021). Investing in student success at community colleges: Lessons from research on guided pathways [Federal policy brief]. Columbia University, Teachers College, Community College Research Center. https://ccrc.tc.columbia.edu/publications/policy-brief-guided-pathways.html

Cooper, S., Hart, C., Kurlaender, M., Rios-Aguilar, C., Rodriguez, F. C., \& Sublett, C. (2020). Turning on a dime: California community college transformation in response to COVID-19. Wheelhouse: The Center for Community College Leadership and Research. https://education.ucdavis.edu/sites/main/files/ucdavis_wheelhouse_research_brief_vol5no2_final.pdf

Deming, D. J., \& Walters, C. R. (2017). The impact of price caps and spending cuts on U.S. postsecondary attainment (NBER Working Paper No. 23736). National Bureau of Economic Research. https://www.nber.org/system/files/working_papers/w23736/w23736.pdf

Fox, K., Bryant, G., Lin, N., Khedkar, N., \& Nguyen, A. (2021). Time for class COVID-19 edition part 3: The Impact of 2020 on postsecondary teaching and learning of introductory faculty. Tyton Partners. https://www.everylearnereverywhere.org/resources/time-for-class-covid-19-edition/

Fox, K., Bryant, G., Lin, N., \& Srinivasan, N. (2020). Time for class-COVID-19 edition part 1: A national survey of faculty during COVID-19. Tyton Partners and Every Learner Everywhere. https://www.everylearnereverywhere.org/wp-content/uploads/TimeforClass-COVID19-Part-1-NationalFacultySurvey-Final.pdf

Glatter, H. (2020, April 7). Emerging challenges the coronavirus poses for community colleges. Community College Research Center. https://ccrc.tc.columbia.edu/ easyblog/challenges-coronavirus-community-colleges.html

Goldrick-Rab, S. (2021). Students are humans first: Advancing basic needs security in the wake of the COVID-19 pandemic. Journal of Postsecondary Student Success, 1(1), 3-17. https://doi.org/10.33009/fsop_jpss129262

Gravely, A. (2021, October 29). Down to $\$ 40$ billion. Inside Higher

Ed. https://www.insidehighered.com/news/2021/10/29/

higher-ed-funding-continues-shrink-social-spending-bill

Institute for Evidence-Based Change. (n.d.). Creating a caring campus - Overview. https://www.iebcnow.org/caring-campus/ 
Jaggars, S. S., \& Stacey, G. W. (2014.) What we know about developmental education outcomes. Columbia University, Teachers College, Community College Research Center. https:/ccrc.tc.columbia.edu/media/k2/attachments/ what-we-know-about-developmental-education-outcomes.pdf

Jenkins, D., Lahr, H., \& Mazzariello, A. (2021). How to achieve more equitable community college student outcomes: Lessons from six years of CCRC research on guided pathways. Columbia University, Teachers College, Community College Research Center. https://ccrc.tc.columbia.edu/publications/equitable-community-college-student-outcomes-guided-pathways.html

Jenkins, D., \& Fink, J. (2021). To build back enrollment, community colleges must ensure that their programs are worth completing. Community College Research Center. https://ccrc.tc.columbia.edu/easyblog/community-college-enrollment-value.html

Karp, M., Ackerson, S., Cheng, I., Cocatre-Zilgien, E., Costelloe, S., Freeman, B., Lemire, S., Linderman, D., McFarlane, B., Moulton, S., O’Shea, J., Porowski, A., \& Richburg-Hayes, L. (2021). Effective advising for postsecondary students: A practice guide for educators (WWC 2022003). U.S. Department of Education, Institute of Education Sciences, National Center for Education Evaluation and Regional Assistance. https://ies.ed.gov/ncee/wwc/PracticeGuide/28

Klempin, S., Kalamkarian, H. S., Pellegrino, L., \& Barnett, E. A. (2019). A framework for advising reform (CCRC Working Paper No. 111). Columbia University, Teachers College, Community College Research Center. https:/ccrc.tc.columbia.edu/publications/framework-advising-reform.html

Lopez Salazar, A., Pellegrino, L., \& Leasor, L. (2020, September 16). How colleges adapted advising and other supports during COVID-19 shutdowns. Community College Research Center. https://ccrc.tc.columbia.edu/easyblog/colleges-adapted-advising-covid-supports.html

McMurtie, B. (2021, March 17). Good grades, stressed students: They struggled with online learning last fall, but not always in ways you might expect.

The Chronicle of Higher Education. https://www.chronicle.com/article/ good-grades-stressed-students

Miller, C., Headlam, C., Manno, M. S., \& Cullinan, D. (2020). Increasing community college graduation rates with a proven model: Threeyear results from the Accelerated Study in Associate Programs (ASAP) Ohio Demonstration. MDRC. https://www.mdrc.org/publication/ increasing-community-college-graduation-rates-proven-model

National Center for Education Statistics. (2021a). Digest of education statistics, Table 303.70 (Total undergraduate fall enrollment in degree-granting postsecondary institutions by attendance status, sex of student, and control and level of institution: Selected years, 1970 through 2029). https:/nces.ed.gov/programs/digest/d20/ tables/dt20_303.70.asp?current=yes 
National Center for Education Statistics. (2021b). Digest of education statistics, Table 306.50 (Total fall enrollment in degree-granting postsecondary institutions, by control and classification of students, level of enrollment, and racelethnicity of student: 2019). https://nces.ed.gov/programs/digest/d20/tables/dt20_306.50.asp

National Center for Education Statistics. (2021c). Number and percentage distribution of students enrolled at Title IV institutions, by control of institution, student level, level of institutions, enrollment status, and other selected characteristics: United States, fall 2020. https://nces.ed.gov/pubsearch/pubsinfo.asp?pubid=2021100

National Student Clearinghouse Research Center. (2020). Current term enrollment estimates, fall 2020. https://nscresearchcenter.org/wp-content/uploads/CTEE_ Report_Fall_2020.pdf

Parker, K., Minkin, R., \& Bennett, J. (2020). Economic fallout from COVID-19 continues to hit lower-income Americans the hardest. Pew Research Center. https:// www.pewresearch.org/social-trends/2020/09/24/economic-fallout-from-covid19-continues-to-hit-lower-income-americans-the-hardest/

Philips, B. C., \& Horowitz, J. E. (2020, June 26). What does it mean to be a caring campus during the COVID-19 pandemic? Community College Research Center. https://ccrc.tc.columbia.edu/easyblog/caring-campus-covid-19.html

Scrivener, S., Weiss, M. J., Ratledge, A., Rudd, T., Sommo, C., \& Fresques, H. (2015). Doubling graduation rates: Three-year effects of CUNY's Accelerated Study in Associate Programs (ASAP) for developmental education students. MDRC. https://www.mdrc.org/publication/doubling-graduation-rates

The Century Foundation. (2019a). Recommendations for providing community colleges with the resources they need. https://tcf.org/content/report/ recommendations-providing-community-colleges-resources-need/

The Century Foundation. (2019b). Restoring the American dream: Providing community colleges with the resources they need. https:/tcf.org/content/book/ restoring-american-dream-providing-community-colleges-resources-need/

U.S. Census Bureau. (2021, October 29). Measuring household experiences during the coronavirus pandemic. https://www.census.gov/data/experimental-data-products/ household-pulse-survey.html

U.S. Department of Education. (2021, July 29). U.S. Department of Education announces $\$ 3.2$ billion in additional higher education emergency relief funds to support students at historic and under-resourced institutions. https://www.ed.gov/ news/press-releases/us-department-education-announces-32-billion-additional-higher-education-emergency-relief-funds-support-students-historic-and-under-resourced-institutions 
Xu, D., \& Xu, Y. (2019). The promises and limits of online higher education:

Understanding how distance education affects access, cost, and quality. American Enterprise Institute. https://www.aei.org/research-products/report/ the-promises-and-limits-of-online-higher-education/ 